\title{
Assessing the Impact of International Fieldwork: The Case of J. F. Oberlin University, Japan
}

\author{
Chisato Igano $^{1} \&$ Hiroshi Ito $^{2}$ \\ ${ }^{1}$ College of Arts and Sciences, J. F. Oberlin University, Tokyo, Japan \\ ${ }^{2}$ Graduate School of Management, Nagoya University of Commerce and Business, Nagoya, Japan \\ Correspondence: Hiroshi Ito, Graduate School of Management, NUCB Business School, Nagoya, Japan. Tel: \\ 81-52-203-8111 E-mail: hito@nucba.ac.jp
}

Received: August 29, 2018

doi:10.5539/ass.v14n10p59
Accepted: September 24, 2018

Online Published: September 28, 2018

URL: https://doi.org/10.5539/ass.v14n10p59

\begin{abstract}
This study examines the impact of international fieldwork in developing students' generic, transferable, life, and soft skills and attributes by comparing reported scores of these skills and attributes through self-evaluation surveys before and after the fieldwork and interviewing students to explore why they think that certain skills and attributes improved while other skills and attributes did not. Findings suggest that the international fieldwork may enhance skills and attributes related to initiative, execution, detecting issues, planning, delivering messages, and flexibility. However, the fieldwork did not seem to enhance skills and attributes to influence others, to listen, to grasp situations, to apply rules, to control stress, and creativity. Possible explanations for certain skills and attributes improvement and stagnation are provided in addition to suggestions for future research.
\end{abstract}

Keywords: fieldwork, skills development, higher education, generic skills, Japan

\section{Introduction}

\subsection{Background}

There is an increasing presence of short-term international fieldwork programs worldwide (Mullens, Bristow, \& Cuper, 2012). This study examines the effectiveness of an international fieldwork program in India offered by J. F. Oberlin University of Tokyo, Japan, focusing specifically on developing generic skills and attributes, such as critical thinking, problem-solving, and creativity, as a mode of teaching and learning. Fieldwork is an important teaching and learning method to acquire such skills that improve student employability (Clarke, 1996; Gonzales \& Semken, 2006; Rydant, Shiplee, Smith, \& Middlekauff, 2010; Wall \& Speake, 2012).

Boyle et al. (2007) define fieldwork as a component of leaving the classroom and learning through first-hand experiences in the real world. Commonly stated aims of fieldwork include the following: 1) to introduce, reinforce, and develop both general and subject-specific skills and attributes; 2) to provide the opportunity for experiential learning; and 3) to develop experience facing the challenges of different socio-cultural environments (McEwen, 1996). That is, fieldwork enables students to acquire skills and attributes though experiential learning in different environments.

Previous research indicates that fieldwork has been perceived positively by both teachers and students (Charles-Edwards, Bell, \& Corcoran, 2014; Connell, 2006; Fuller et al., 2003; Fuller et al., 2006; Goodenough et al., 2014; Hope, 2009). Fieldwork can be a pedagogical tool for directing student attention (McMorran, 2015) and problem-solving student-centered learning (Dalton, 2001). Fieldwork offers opportunities to encourage different types of teaching and learning and to reflect on what effective learning might be in this context (Coe \& Smyth, 2010). Wilson (2008) and Goodenough et al. (2014) also explain that fieldwork is an important element of many undergraduate degree courses. It provides students with opportunities to deepen their understanding of the connections between theory and practice through active, immersive, and inquiry-based learning. Mullens et al. (2012) also argue that international fieldwork provides an opportunity to enhance what they have learned in the classroom, which sometimes cannot be covered by local/regional/national fieldwork. For instance, issues that India can be learnt in the classroom but cannot certainly addressed in the real world context unless being there. 


\subsection{Fieldwork as a Learning Strategy and Skills Development Mechanism}

Fieldwork has evolved from simple observations into a wider variety of learning and teaching processes, such as active learning (Fuller et al., 2006, pp. 90-91), experiential learning (McEwen, 1996), and reflective learning (Dummer et al., 2008), all of which can be interrelated and lead to deep learning (Coe \& Smyth, 2010; Hill \& Woodland, 2002; Matsushita, 2017). Deep learning refers to learning that encompasses the acquisition and application of higher order skills, such as analyzing and interpreting data in order to encourage students to modify or evaluate their ideas or knowledge through a critical reflection process (Moon, 2005). Dummer et al. (2008) argues that reflective learning constitutes a principal part of deep learning. Dummer et al. continue to say that Kolb's (1984) experiential learning theory serves for discussions on reflective learning.

Kolb's learning cycle outlines how learners use experiences, observations, and reflections to help understand concepts and create new ideas. Gibbs (1988) defines such a process as active learning (learning by doing) promoted by reflecting on what we are doing. In active learning and experiential fieldwork, by definition, students learn by applying theories into practice (Gibbs, 1988) and learn by actively engaging in all four aspects of Kolb's learning cycle (Dummer et al., 2008; Pelley, 2014). However, the assessment of reflective learning can be problematic in part because it is difficult to observe (Dummer et al., 2008; Wilson, 2008). In this context, we employ skills/attributes development measurement. Fieldwork helps develop generic, transferable, research, and life skills such as critical thinking, analytical reasoning, problem solving, and communication skills, teamwork, and leaderships (Dalton, 2001; Everill, 2015; Fuller et al., 2006; Ito \& Kawazoe, 2015; McEwen, 1996; Panelli \& Welch, 2005; Pawson \& Teather, 2002; Smith, 2004) as well as awareness of cultural difference (Hay \& O'Donoghue, 2009). There are scarce international studies on the role of fieldwork and its effectiveness in developing skills and attributes (Fuller et al., 2006). The current research intends to close the gap by offering a case-study of an international fieldwork program offered by J. F. Oberlin University in Tokyo, Japan.

\subsection{International Fieldwork at J. F. Oberlin University}

J. F. Oberlin University is a private university founded in Tokyo in 1921. It is named after Oberlin College in Ohio where the university's founder attended. J. F. Oberlin University's Department of International Cooperation aims to help students learn about the current status and causes of global issues such as environmental degradation, poverty, and violation of human rights. In this context, the department provides students with fieldwork opportunities to learn about specific development issues such as gender discrimination and child protection through a two-week international program in Bangalore, South India. In 2018, 14 sophomore-to-senior students voluntarily participated in the program.

The country is located in a relatively convenient area from Japan, an approximately eight to nine hour flight with two hour time difference. This may be an important factor because the increased travel time exhaust staff and students and jet lag may adversely affect the performance (Fuller, 2006).

In the first half of the fieldwork experience, students stay in Bangalore, working with a local NGO. They visit slums, interview sex workers infected with HIV/AIDS, and interact with street children to contemplate issues of poverty, gender, and child education in the city. In the second half of the fieldwork, students stay at VEDIKE (a private nonprofit organization that provides schooling children who cannot receive formal education) in the suburban area of Bangalore. In addition to daily interactions with children at VEDIKE, students also collaborate in the construction of school buildings and lodging houses. As Nash (2000) notes, fieldwork may involve voluntary work like this or other research work, which could contribute to an undergraduate product.

Also, through homestay with the women's groups in the surrounding villages, students are given opportunities to consider the disparity between urban and rural areas. By experiencing the environment close to the lives of local people, students begin to understand the current situation and real problems. After returning to Japan, students think about how they could address the issues of developing countries.

The fieldwork offered by Oberlin University is an example of service learning and the following are taken as important aspects of the program: 1) through social activities conducted through on-site-training, students engage in addressing issues that local people face in the community and 2) students raise awareness, enhance sensitivity, and acquire generic and transferable skills/attributes. The goal of the fieldwork course incorporating service learning is to acquire the abilities and attitudes that are mentioned in syakaijin kisoryoku, a conceptual set of skills and attributes promoted by the Ministry of Economy, Trade and Industry of Japan (2014), which will be discussed in the next section.

\section{Method}

There has been considerable debate on competency-based assessment such as which competencies need to be 
achieved and how such competencies can be measured (Dummer et al., 2008; Hay \& O'Donoghue, 2009, p. 43). The current research focuses on syakaijin kisoryoku. These are generic, transferable, research, and life skills/attributes that are considered fundamental for working persons (See Ito \& Kawazoe, 2015, for more details). Syakaijin kisoryoku, skills/attributes to be measured in the current research, are described as follows:

1. Initiative: Ability to initiate things proactively

2. Ability to influence: Ability to influence and involve others

3. Execution skill: Ability to set goals and execute with conviction

4. Ability to detect issues: Ability to analyze status quo and clarify issues

5. Planning skill: Ability to clarify procedures to solve issues and prepare

6. Creativity: Ability to create new values

7. Ability to deliver messages

8. Ability to listen closely and carefully

9. Flexibility

10. Ability to grasp situations

11. Ability to apply rules and regulations

12. Ability to control stress

It is hypothesized that these skills and attributes improved after the fieldwork experience of living in a different environment, interacting with people from another country, and doing various assignments such as a project write-up (Nash, 2000) and reflective journals and essays (Hay \& O’Donoghue, 2009). Writing assignments are particularly important to improve students' generic and transferable skills and attributes because as Dummer et al. (2008) as well as Park (2003) note, reflective fieldwork written assignment "offer an innovative and flexible approach to teaching, learning and assessment that encourages deep learning. The method enhances students' critical self-reflection and communication skills" (Dummer et al., 2008, p. 459).

The methods to assess the changes in these skills/attributes are student self-survey evaluation and semi-structured interviews with questions based on the self-evaluations. The self-evaluation uses the five Likert scale from 1 indicating very bad to 5 indicating very good. We then conduct semi-structured interviews to ask participants why they thought that some skills and attributes improved while others did not after the fieldwork. The number of students who participated in the study is eight (three males and five females). The results of the self-evaluation were analyzed using t-test to identify skills/attributes that have changed statistically signify before and after the international fieldwork.

\section{Results}

Table 1. Self-evaluation surveys in syakaijin kisoryoku before (left) and after (right) the fieldwork

\begin{tabular}{|c|c|c|c|c|c|c|c|c|c|c|c|c|c|c|c|c|c|c|c|c|c|c|c|c|}
\hline \multirow{2}{*}{$\begin{array}{c}\text { Name } \\
\text { Mayuko }\end{array}$} & \multirow{2}{*}{$\begin{array}{c}\text { Sex } \\
F\end{array}$} & Initiative & \multicolumn{2}{|c|}{ Influeincing } & \multicolumn{2}{|c|}{ Execution } & \multicolumn{2}{|c|}{ Petect issues } & \multicolumn{2}{|c|}{ Planning } & \multicolumn{2}{|c|}{ Creativity } & \multicolumn{2}{|c|}{ Delivering messages } & \multicolumn{2}{|c|}{ Listening } & \multicolumn{2}{|c|}{ Flexibility } & \multicolumn{2}{|c|}{ Frasping situations } & \multicolumn{2}{|c|}{ Applying rurles } & \multicolumn{2}{|c|}{ Controling stress } \\
\hline & & 3 & 2 & 3 & 2 & 3 & 3 & 3 & 3 & 3 & 3 & 3 & 2 & 3 & 3 & 3 & 2 & 3 & 3 & 3 & 3 & 3 & 2 & 2 \\
\hline Yuzuka & $\mathrm{F}$ & 4 & 3 & 3 & 2 & 3 & 3 & 4 & 2 & 3 & 3 & 3 & 3 & 3 & 3 & 3 & 3 & 4 & 3 & 3 & 3 & 3 & 3 & 3 \\
\hline Akashi & M & 3 & 2 & 4 & 2 & 3 & 3 & 3 & 2 & 3 & 3 & 3 & 3 & 3 & 4 & 4 & 2 & 4 & 3 & 3 & 2 & 2 & 5 & 5 \\
\hline Syota & M & 5 & 5 & 5 & 4 & 5 & 4 & 4 & 5 & 5 & 4 & 4 & 4 & 5 & 5 & 5 & 4 & 5 & 5 & 5 & 5 & 5 & 3 & 3 \\
\hline Harune & $\mathrm{F}$ & 3 & 3 & 3 & 4 & 4 & 3 & 4 & 4 & 4 & 4 & 4 & 2 & 3 & 3 & 3 & 4 & 4 & 3 & 3 & 3 & 4 & 3 & 3 \\
\hline Chinatsu & $\mathrm{F}$ & 2 & 2 & 3 & 4 & 4 & 2 & 4 & 3 & 4 & 3 & 3 & 2 & 2 & 4 & 5 & 5 & 5 & 4 & 5 & 4 & 5 & 5 & 5 \\
\hline Total & & $25 \#$ & & & 23 & 27 & 24 & 29 & 24 & 27 & 24 & 25 & 20 & 23 & 28 & 30 & 27 & 33 & 26 & 27 & 26 & 28 & 27 & 27 \\
\hline Ave. & & $3.13 \#$ & 2.753 & 3.25 & 2.883 & 3.38 & 3.00 & 3.63 & 3.003 & 3.38 & 3.00 & 3.13 & 2.50 & 2.88 & 3.50 & 3.75 & 3.38 & 4.13 & 3.25 & 3.38 & 3.25 & 3.50 & 3.38 & 3.38 \\
\hline Sig. & & $0.025 *$ & 0.052 & & $0.017 *$ & & 0.025 & & $0.04 *$ & & 0.18 & & $0.0398 *$ & & 0.1 & & 0.01 & $* *$ & 0.175 & & 0.09 & & & \\
\hline
\end{tabular}

$* \mathrm{p}<0.05, * * \mathrm{p}<0.01$

According to the results of the student self-survey evaluation, skills related to initiative, execution, detecting issues, planning, and delivering messages statistically significantly improved at the .01 level, and flexibility statistically significantly improved at the .05 level after the international fieldwork in India.

We then conducted semi-structured interviews to ask them why they thought that some skills and attributes improved while others did not after the fieldwork.

Mayuko reported that her execution skills and ability to deliver messages improved by one point. Before going 
to the fieldwork, she thought that there was no need to tell someone her thoughts. However, she has begun to make efforts to inform people of what she knows and what they may not know. After she came back to Japan from India, she became much more active. For instance, she has been involved in the activities of Oxfam, a British originated, humanitarian aid NPO/NGO. Before, she did not trust NPOs in part because she was not sure how the money they fundraised was used. After working with a local NGO in India, she has a concrete idea of what NPOs are doing and would like people around her to understand it, too. Yuzuka reported that her execution skills, planning skills, and flexibility improved by one point respectively. She claims that she was originally a person without execution and planning skills. Even if she made a plan, she could not carry it out. Since she came back from the fieldwork in India, however, she feels that she has more planning and execution skills. She remembers that the street children that she interacted in India studied hard to learn to write or speak English. That experience made her realize how lucky she is and that she has to make more efforts toward setting and achieving goals. She also feels that she has become more flexible because she faced many kinds of cultural differences in India, such as not throwing toilet papers into the urinal or having to sleep with a dirty blanket.

Akashi reported that his execution skills improved by one point and flexibility by two points. Before he went to the fieldwork in India, she had no execution skills. Afterwards, he did and interacted with many different kinds of people. He became interested in many things, such as the issues of poverty. After she came back to Japan, he is now able to make a plan and carry it out. He started working with homeless people or people in poor areas, for example. Regarding flexibility, at first, she had no idea what to do about cultural and language differences between Japanese and India. However, through interactions with many people with different backgrounds, she now understands cultural differences better and feels much more flexible than before.

Syota claimed that his execution skills and flexibility improved by one point. He explained that he thought that he originally had execution skills but they were enhanced after he went to the fieldwork and saw a harsh reality in India. He then became more active, for example, collecting information and doing research to analyze the situation in India. Regarding flexibility, now that Japanese and others have different ways of thinking, he can now accept the opinions of others as they are, without denying them. Even if he tells people to change, they will not. He has to deal with them flexibly.

Haruyuki reported that her skills related to initiative, detecting issues, creativity, listening to others, and flexibility improved by one point respectively. He said that he started telling people his experiences in India. For example, he now conducts workshops about international development issues and tell audience what she learned in India. He feels that she has more initiative than before when she tells people what she learns. Before, she had prejudice against issues faced by India. She thought that few households had electricity and TVs. After she went there, however, he faced different issues: toilets and/or domestic waste water were dirty and could do harm to one's health. She also reported that because he was in a different environment from that of Japan, his imagination has enhanced and thus his creativity also enhanced. In India, he talked to people with different cultures as well as socio-economic backgrounds. When he meets people with different values in Japan, he can now respect them. Before the fieldwork, he tried avoiding them. Also in India, she was in an environment that was totally different from that of Japan, she became much more flexible now.

Chika reported that skills related to initiative improved by two points, and skills related to detecting issues, planning, listening, grasping situations, applying rules and regulations improved by one point. She said that she was not an active person before but became more active during the fieldwork in India. Looking at people who struggle to live hard, she came to think that she could do more and how to achieve it. For instance, there was an activity to carry blocks to build a school for street children. She made efforts to elaborate on how to do it more effectively. She thinks that she has gained ability to examine surrounding situations and find issues. For instance, she had a prototype that Indian women were socially disadvantaged. After observing them in India, however, they are not as discriminated against as expected. She said that she did not have planning skills. She used to just think and do things. However, through the variety of assignments such as post-fieldwork reports, she started to write long term as well as short-term goals in her agenda and to think how she could achieve them. She noted that overseas, where languages and cultural contexts are different, we would not be able to get any information without efforts to ask and listen to actively and carefully. She claimed that there is a gap between what students learn in the classroom and issues faced in the field. She realized it while in India. For instance, she learned about issues of gender and discrimination against women in the classroom, but she found children's education more problematic there when she actually saw it. This kind of gap between what is learned in the classroom and what is seen in the field seems common (Mullens et al., 2012). Also, before, she was not aware of rules and regulations. After going to India, yet, she became aware of the importance of rules and regulations because they are not respected in India. 
Harune claimed that skills related to initiative, detecting issues, delivering messages, and applying rules and regulations improved by one point. Right after doing the fieldwork, she started job hunting. She had been interested in the fashion industry, but now she is aware that many factories in the fashion industry are located in developing countries. Although she has been studying international cooperation, the industry that she would like to work in may be exploiting developing countries. However, though the industry itself may be exploiting, there is something that she could do for developing countries, such as volunteering.

Mutsumi reported that all the skills and attributes remained the same before and after the fieldwork.

\section{Discussion}

This study suggests that international fieldwork may enhance skills/attributes related to initiative, execution, detecting issues, planning, delivering messages, and flexibility, as these skills and attributes improved statistically significantly after the fieldwork. Although the students who participated in the fieldwork learned these skills and attributes in various contexts, how these skills are developed through fieldwork is often difficult to analyze. Indeed, few studies "delve beyond the surface into a more systematic framework for skills development or authentic assessments of their efficacy (Rydant et al., 2010, p. 221).

The skills and attributes that significantly improved through the fieldwork are initiative, execution, detecting issues, planning, delivering messages, and flexibility. Among them, improving skills related to initiative and execution require students' heightened proactiveness. Perhaps, this process occurs, as fieldwork stimulates independent learning whilst providing for the development of personal skills (May, 1999) and boost students' self-confidence (Wall \& Speake, 2012). Regarding skills related to detect issues, as Rydant et al. (2010) note, fieldwork helps develop observational skills, which enables students to think critically about form and process and thus find and examine issues (Rydant et al., 2010).

As for planning, as a respondent of the current research also mentioned, fieldwork involves designing of fieldwork activities and assignments, including organizing daily work program and time management (Rydant et al., 2010). This helps students to learn to make plans. Concerning skills to deliver messages, by exposing themselves to new and different landscapes, students develop awareness of features, learning to describe and articulate impressions (Rydant et al., 2010).

With respect to flexibility, as Wall and Speake (2012) note, international fieldwork develops "a distinctive and somewhat different set of competencies including a potential understanding and tolerance of cultural differences" (p. 431). They continue to state that "observations and experiences as cultural outsiders (others) themselves exemplifying the process of 'othering' whilst challenging the stereotype central to it" (Wall \& Speake, 2012, p. 431). Hence, international fieldwork certainly helps students become more flexible in thinking and behavior.

Although no skills and attributes were reported deteriorated, there were skills/attributes that did not improve significantly: skills/attributes pertained to influencing others, creativity, listening, grasping situations, applying rules, and controlling stress. Given that skills to deliver messages improved, it is a little surprising that the skill to influence others did not because these two skills seem relevant. While students are more expressive now, they may not intend to influence others after being in an environment where they were primarily influenced by others rather than influencing others. Also, if we take a closer look, the significant level of this item (i.e., skills to influence others) is .052 before and after the fieldwork and thus the improvement is almost statistically significant. It may also be surprising that creativity did not improve, either. As Dyer et al. (2011) note, having stayed in a foreign country likely enhances creativity. However, creativity may not be a skill or attribute that can be improved within a few weeks. Also, the nature of the work does not seem focused on creativity. Future research should take this point into account and examine a longer fieldwork and/or a fieldwork that focuses on enhancing creativity. It may be odd that abilities to listen and grasp situations did not improve because abilities to deliver messages or detect issues, which seem relevant to these skills, improved. There may be some possible explanations for this such as language barriers as local people spoke their native languages and students were not comfortable with even understanding English. These are issues to be addressed by future research.

The ability to apply rules did not improve possibly because rules may not be as strictly respected in India as in Japan. Therefore, students may not have been aware of this ability while being there. Ability to control stress did not improve, either. This may be because those were willing to go to India expected a harsh condition even before going there and thus did not feel stressed as much as expected.

\section{Conclusion, Limitations, and Future Research}

The current research indicates that the international fieldwork can enhance skills/attributes related to initiative, execution, detecting issues, planning, delivering messages, and flexibility, whereas skills/attributes pertaining to 
influencing others, creativity, listening, grasping situations, applying rules, and controlling stress did not improve significantly. One limitation of the current research is that it asked students why certain skills/attributes improved after or during the fieldwork, but it did not ask them why certain skills/attributes did not. Future research should address this issue. Also, the current research only examined one two-week fieldwork course in India and findings cannot be generalized. Therefore, future research should analyze longer-term fieldwork courses in different places. It may also be interesting to examine how these same students see this fieldwork experience as a formative role in developing their skill set in five or ten years. Nevertheless, the current research provides a case-study of fieldwork in an international setting. Given that few studies on international fieldwork in developing skills/attributes exist, we expect the current research will make a contribution to this area.

\section{Acknowledgments}

I would like to thank students who participated in this study. I would also like to thank Mr. Ezra Antone Greene for editing this paper.

\section{References}

Boyle, A., Maguire, S., Martin, A., Milson, C., Nash, R., Rawlinson, S., ... Conchie, S. (2007). Fieldwork is good: The student perception and the affective domain. Journal of Geography in Higher Education, 31, 299-317. https://doi.org/10.1080/03098260601063628

Charles-Edwards, E., Bell, M., \& Corcoran, J. (2014). Integrating undergraduate fieldwork into the study of human mobility. Australian Geographer, 45(4), 505-519. https://doi.org/10.1080/00049182.2014.953734

Clarke, D. (1996). The changing national context of fieldwork in geography. Journal of Geography in Higher Education, 23(3), 385-398. https://doi.org/10.1080/03098269608709381

Coe, N. M., \& Smyth, M. (2010). Students as tour guides: Innovation in fieldwork assessment. Journal of Geography in Higher Education, 34(1), 125-139. https://doi.org/10.1080/03098260902954095

Connell, J. (2006). "I can't eat that, it's purple": A geography field course in Vanuatu and Fiji. Geographical Research, 44(1), 17-27. https://doi.org/10.1111/j.1745-5871.2006.00357.x

Dalton, R. (2001). What do they bring with them? The fieldwork experiences of undergraduates on entry into higher education. Journal of Geography in Higher Education, 25(3), 379-393. https://doi.org/10.1080/03098260120067673

Dummer, T. J., Cook, I. G., Parker, S. L., Barrett, G. A., \& Hull, A. P. (2008). Promoting and assessing "deep learning" in geography fieldwork: An evaluation of reflective field diaries. Journal of Geography in Higher Education, 32(3), 459-479. https://doi.org/10.1080/03098260701728484

Dyer, J. H., Gregersen, H., \& Cristensen, C. M. (2011). The innovator's DNA: Mastering the five skills of disruptive innovators. Boston: Harvard Business Review Press.

Everill, P. (2015). Pedagogy and practice: The provision and assessment of archaeology fieldwork training in UK higher education. The Historic Env., 6(2), 122-141. https://doi.org/10.1179/1756750515Z.00000000078

Fuller, I. C. (2015). Facilitating international fieldwork: The receptive services of New Zealand's geography community. J. of Geo. in Higher Edu., 39(4), 513-526. https://doi.org/10.1080/03098265.2015.1084609

Fuller, I. C., Edmondson, France, D., Higgitt, D., \& Ratinen, I. (2006). International perspectives on the effectiveness of geography fieldwork for learning. Journal of Geography in Higher Education, 30(1), 89-101. https://doi.org/10.1080/03098260500499667

Fuller, I. C., Gaskin, S., \& Scott, I. (2003). Student perceptions of geography and environmental science fieldwork in the light of restricted access to the field, caused by foot and mouth disease in the UK in 2001. Journal of Geography in Higher Education, 27(1), 79-102. https://doi.org/10.1080/0309826032000062487

Gibbs, G. (1988). Learning by doing. London: LEU.

Gold, J. R., Jenkins, A., Lee, R., Monk, J., Riley, J., Shepherd, I. D. H., \& Unwin, D. J. (1991). Teaching geography in higher education. Oxford: Blackwell.

Gonzales, D., \& Semken, S. (2006). Integrating undergraduate education and scientific discovery through field research in igneous petrology. Journal of Geoscience Education, 54(2), 133-142. https://doi.org/10.5408/1089-9995-54.2.133

Goodenough, A. E., Rolfe, R. N., MacTavish, L., \& Hart, A. G. (2014). The role of overseas field courses in student learning in the biosciences. Bioscience Education. https://doi.org/10.11120/beej.2014.00021 
Hay, K., \& O'Donoghue, K. (2009). Assessing social work field education: Toward standardizing fieldwork assessment in New Zealand. Social Work Education, 28(1), 42-53. https://doi.org/10.1080/02615470802020881

Healey, M. (2005). Linking research and teaching to benefit student learning. Journal of Geography in Higher Education, 29(2), 183-201. https://doi.org/10.1080/03098260500130387

Hill, J., \& Woodland, W. (2002). An evaluation of foreign fieldwork in promoting deep learning: a preliminary investigation. Assessment and Evaluation in Higher Education, 27(6), 539-555. https://doi.org/10.1080/0260293022000020309

Hope, M. (2009). The importance of direct experience: A philosophical defense of fieldwork in human geography. J. of Geography in Higher Edu., 33(2), 169-182. https://doi.org/10.1080/03098260802276698

Ito, H., \& Kawazoe, N. (2015). Active learning for creating innovators. International Journal of Higher Education, 4(2), 81-91. https://doi.org/10.5430/ijhe.v4n2p81

Kolb, D. A. (1984). Experiential learning. London: Prentice-Hall.

Matsushita, K. (2017). Deep active learning: Toward greater depth in university education. New York: Springer.

May, J. (1999). Developing fieldwork in social and cultural geography: Illustration from a residential field class in Los Angeles and Las Vegas. Journal of Geography in Higher Education, 23(3), 207-225. https://doi.org/10.1080/03098269985470

McEwen, L. (1996). Fieldwork in the undergraduate geography program: Challenges and changes. Journal of Geography in Higher Education, 20(3), 379-384. https://doi.org/10.1080/03098265.2015.1084495

McMorran, C. (2015). Between fan pilgrimage and dark tourism: Competing agendas in overseas field learning. Journal of Geography in Higher Education, 39(4), 568-583.

Nash, D. J. (2000). Doing independent overseas fieldwork 1: Practicalities and pitfalls. Journal of Geography in Higher Education, 24(1), 139-149. https://doi.org/10.1080/03098260085234

Panelli, R., \& Welch, R. V. (2005). Teaching research through field studies: A cumulative opportunity for teaching methodology to human geography undergraduates. Journal of Geography in Higher Education, 29(2), 255-277. https://doi.org/10.1080/03098260500130494

Park, C. (2003). Engaging students in the learning process: The learning journal. Journal of Geography in Higher Education, 24, 246-254. https://doi.org/10.1080/0309826032000107496

Pawson, E., \& Teather, E. K. (2002). "Geographical Expeditions": Assessing the benefits of a student-driven fieldwork method. Journal of Geography in Higher Education, 26(3), 275-289. https://doi.org/10.1080/0309826022000019864

Pelley, J. (2014). Making active learning effective. Medical Science Education, 24, 13-18. https://doi.org/10.1007/s40670-014-0087-1

Rabiee, F. (2004). Focus-group interview and data analysis. Proceedings of the Nutrition Society, 63, 655-660. https://doi.org/10.1079/PNS2004399

Robson, E. (2002). "An unbelievable academic and personal experience": Issues around teaching undergraduate field courses in Africa. Journal of Geography in Higher Education, 26, 327-344. https://doi.org/10.1080/0309826022000019909

Rydant, A. L., Shiplee, B. A., Smith, J. P., \& Middlekauff, B. D. (2010). Applying sequential fieldwork skills across two international field courses. Journal of Geography, 109, 221-232. https://doi.org/10.1080/00221341.2010.502945

Smith, D. (2004). Issues and trends in higher education biology fieldwork. Journal of Biological Education, 39(1), 6-10. https://doi.org/10.1080/00219266.2004.9655946

Wall, G. P., \& Speake, J. (2012). European geography higher education fieldwork and the skills agenda. Journal of Geography in Higher Education, 36(3), 421-435. https://doi.org/10.1080/03098265.2011.641110

\section{Copyrights}

Copyright for this article is retained by the author(s), with first publication rights granted to the journal.

This is an open-access article distributed under the terms and conditions of the Creative Commons Attribution license (http://creativecommons.org/licenses/by/4.0/). 